\title{
Experimental Study of Hydrogasification of Lignite and Subbituminous Coal Chars
}

\author{
Stanisław Gil ${ }^{1}$ and Adam Smoliński \\ ${ }^{1}$ Institute of Metals Technology, Silesian University of Technology, Krasinskiego 8, 40-019 Katowice, Poland \\ ${ }^{2}$ Department of Energy Saving and Air Protection, Central Mining Institute, Plac Gwarków 1, 40-166 Katowice, Poland \\ Correspondence should be addressed to Adam Smoliński; smolin@gig.katowice.pl
}

Received 15 October 2014; Revised 25 March 2015; Accepted 27 March 2015

Academic Editor: Levent Ballice

Copyright (C) 2015 S. Gil and A. Smoliński. This is an open access article distributed under the Creative Commons Attribution License, which permits unrestricted use, distribution, and reproduction in any medium, provided the original work is properly cited.

\begin{abstract}
The experimental facility for pressure hydrogasification research was adapted to the pressure of $10 \mathrm{MPa}$ and temperature of $1300 \mathrm{~K}$, which ensured repeatability of results and hydrogen heating to the process temperature. A hydrogasification reaction of chars produced from two rank coals was investigated at temperatures up to $1173 \mathrm{~K}$, pressures up to $8 \mathrm{MPa}$, and the gas flow rates of $0.5-$ $5 \mathrm{dm}_{\mathrm{n}}{ }^{3} / \mathrm{min}$. Reactivity of the "Szczerców" lignite char was found to be slightly higher than that of the subbituminous "Janina" coal char produced under the same conditions. A high value of the char reactivity was observed to a certain carbon conversion degree, above which a sharp drop took place. It was shown that, to achieve proper carbon conversion, the hydrogasification reaction must proceed at a temperature above $1200 \mathrm{~K}$.
\end{abstract}

\section{Introduction}

Coal gasification involves carbon conversion in the presence of gasifying medium (oxygen, hydrogen, water steam, carbon dioxide, or others) into gaseous products which, following suitable processing, are used for chemical and/or energy industry purposes as a synthesis gas.

Placing coal in the hydrogen atmosphere at increased temperature and pressure results in a two-stage process: (a) hydropyrolysis where volatile matter released from coal reacts with hydrogen to produce primary, methane-rich gas as well as liquid products and solid char, which is highly reactive during the initial stage, (b) hydrogasification of the char of a high initial reactivity which decreases with the gasification degree. For the char, the hydrogasification rate is the highest immediately after coal devolatilisation and it decreases with the gasification degree accordingly to a proposed by Johnson [1] exponential function, which was expanded by Mühlen [2] to a char gasification degree- and process temperaturedependent relationship.

Hydrogasification is an exothermal reaction between hydrogen and carbon

$$
\mathrm{C}+2 \mathrm{H}_{2} \longrightarrow \mathrm{CH}_{4}+74.9 \mathrm{~kJ} / \mathrm{kmol}
$$

where the reaction product is methane. The principles of hydrodynamic equilibrium in the $\mathrm{H}_{2}-\mathrm{CH}_{4}$-C system suggest that, to obtain a high molar fraction of methane in the resulting $\mathrm{H}_{2}-\mathrm{CH}_{4}$ mixture, the hydrogasification process must be performed at high pressure. A kinetic mechanism of hydrogasification, where a term of free active centres is applied, was proposed by Blackwood [3, 4].

Mühlen [2] studied the effects of pressure on the process rate during coal char gasification in the $\mathrm{H}_{2}, \mathrm{H}_{2} \mathrm{O}$, and $\mathrm{CO}_{2}$ atmospheres. He presented a comparison of the process rates for the three types of char gasification under $T=$ $1173 \mathrm{~K}$ isothermal conditions as a pressure function and the temperature function at $p=2 \mathrm{MPa}$. Mühlen demonstrated that the effect of pressure on the hydrogasification rate was different from that observed during gasification in $\mathrm{H}_{2} \mathrm{O}$ and $\mathrm{CO}_{2}$. A characteristic maximum rate of char gasification in $\mathrm{H}_{2} \mathrm{O}$ and $\mathrm{CO}_{2}$ at as low pressures as approximately $2 \mathrm{MPa}$ was observed. For the whole pressure range, the gasification rate in $\mathrm{H}_{2} \mathrm{O}$ was more than threefold higher than the gasification rate in $\mathrm{CO}_{2}$. For low pressures, hydrogasification was the slowest and it did not reach the gasification rate in $\mathrm{CO}_{2}$ until the pressure of approximately $4 \mathrm{MPa}$ was attained. For the gasification rate in $\mathrm{H}_{2} \mathrm{O}$, a pressure of approximately $10 \mathrm{MPa}$ 
was necessary. Moreover, hydrogasification rate reduction was observed for higher char conversion rates.

In the initial stage of coal gasification, called hydropyrolysis, hydrogen is essential due to its effect on primary tar and the solid carbon skeleton. Coal pyrolysis in the presence of hydrogen markedly increases carbon conversion to gaseous $\mathrm{C}_{1}-\mathrm{C}_{3}$ hydrocarbons, even at relatively low pressures $[5,6]$. Under proper conditions and in the presence of hydrogen, coal pyrolysis products of high molecular mass are mainly conversed to methane. Thus, hydropyrolysis may be considered as a hydrogasification part with very short residence times.

Moseley and Paterson [7] made an attempt to describe coal hydrogasification as simultaneous stages of coal hydropyrolysis and char hydrogasification. Their model was further expanded by Zahradnik and Glenn [8] by applying the concept of active centres, introduced by Blackwood [3] into the mechanism of char hydrogasification.

Anthony et al. [9] studied loss of a coal sample mass during its rapid heating to the final temperature and holding it for 5-20 s under the inert and hydrogen atmospheres. At temperatures above $873 \mathrm{~K}$, hydrogen at $6.9 \mathrm{MPa}$ increased the overall mass loss. For methane, an increased yield was also observed in the hydrogen atmosphere at the temperature above $773 \mathrm{~K}$ and the pressure of $6.9 \mathrm{MPa}$. Suuberg et al. [10] performed similar, and the most frequently cited in the scientific literature, studies on hydropyrolysis.

On the other hand, effects of the atmosphere on amounts of liquid products released at higher pressures are ambiguous. Any comparisons between results obtained by various authors are difficult to perform due to different types of coal used in investigations, differences between experimental devices, and diverse understanding of the term "liquid products" or "tar." In the literature, descriptions of studies conducted by four independent authors for the same Westerholt coal under the inert and hydrogen atmospheres can be found. In their investigations, Bunthoff [11] and Krabiell [12] used a thermobalance, Kaiser [13] applied the Curie point method, and Treuling [14] devolatilised a relatively large $500 \mathrm{~g}$ coal sample in a fixed bed. It should be noted that, in the inert atmosphere, comparable amounts of liquid products per coal mass unit were obtained despite definitely different heating rates varying between $0.05 \mathrm{~K} / \mathrm{s}$ and $9000 \mathrm{~K} / \mathrm{s}$. In the hydrogen atmosphere, on the other hand, differences were significant but there were evidently comparable amounts of liquid products reported in the studies conducted by Kaiser [13] and Treuling [14]. An analysis of qualitatively different curve courses according to Krabiell [12] and Bunthoff [11] requires an in-depth understanding of the definition of the term "liquid products" used by individual researchers.

A major disadvantage of hydrogasification process is the requirement for high temperatures and pressures, which affects the economy of industrial facilities. An application of catalysts is a solution to some problems that occur during hydrogasification as there is a potential for conducting the process at a lower temperature. Certain minerals and metals that show a catalytic effect on hydrogasification reactions are particularly attractive. Alkali metals, due to their high activity and availability, have become a subject of great interest for researchers. The aims of catalyst use are as follows: to increase a carbon conversion rate in the gasification reactor, to reduce a gasification temperature, and to affect selectively a composition of produced gas. The catalytic effect can be observed both in a heterogeneous reaction on the char surface and in a homogeneous reaction in the gaseous phase. The gaseous phase reactions are also affected by fly ash while the char surface reactions are influenced by minerals dispersed in its particles.

Experiments have revealed that catalyst-related advantages are particularly important for these gasification methods where the reaction intensity cannot be enhanced in a conventional way by increasing temperature, for example, direct coal gasification into methane or allothermal gasification using an external, diaphragm heat supply.

Further temperature reduction can be achieved when eutectic salts and their mixtures are applied as catalysts. Because improved catalyst contact with coal results in increased gasification rate, a concept of liquid catalytic salts with the ability of better penetrating macropores in the coal (char) structure that leads to increased carbon conversion is adopted. Thus, eutectic salts with markedly lower melting points than those of pure salts should enhance catalytic gasification at low temperatures.

Sheth et al. [15] presented experiments regarding effects of the $\mathrm{H}_{2} / \mathrm{H}_{2} \mathrm{O}$ ratio on char conversion time during gasification at $1005 \mathrm{~K}$ and $2.64 \mathrm{MPa}$ with a catalyst $\left(43.5 \% \mathrm{Li}_{2} \mathrm{CO}_{3}, 31.5 \%\right.$ $\mathrm{Na}_{2} \mathrm{CO}_{3}$, and $25 \% \mathrm{~K}_{2} \mathrm{CO}_{3}$ ) mixed in a $10 \%$ mass proportion with the Illinois number 6 coal before devolatilisation at $1023 \mathrm{~K}$. The investigations showed an inhibiting effect of hydrogen on the gasification rate. The hydrogasification $\left(\mathrm{H}_{2} / \mathrm{H}_{2} \mathrm{O}=\infty\right)$ was far slower than gasification in the presence of water steam $\left(\mathrm{H}_{2} / \mathrm{H}_{2} \mathrm{O}=0\right)$. The rate of hydrogasification with this catalyst was 0.0019 per minute and approximately 4 -fold higher than the rate of hydrogasification without a catalyst. It should be noted here that the results are comparable to calculations performed by Mühlen [2] for the Fürst Leopold coal.

The aim of the paper is to present the experimental results of the "Janina" and "Szczerców" coal char hydrogasification and to determine the effects of process parameters, such as pressure, temperature, and reactivity, on coal hydrogasification. In particular, the investigations were focused on a relationship between reactivities of chars and conversion rates, which is technologically important. Moreover, comparative investigations of coal hydrogasification and char gasification in the $\mathrm{H}_{2}+\mathrm{CO}_{2}$ atmosphere were performed.

Due to difficulties with respect to a coal hydrogasification description, resulting mainly from simultaneous coal hydropyrolysis and hydrogasification of the remaining char, a mathematical model of char hydrogasification (described in [16]) was only developed.

\section{Materials and Methods}

A schematic diagram of the experimental facility is presented in Figure 1(a). A pressure reactor allows for hydrogasification 


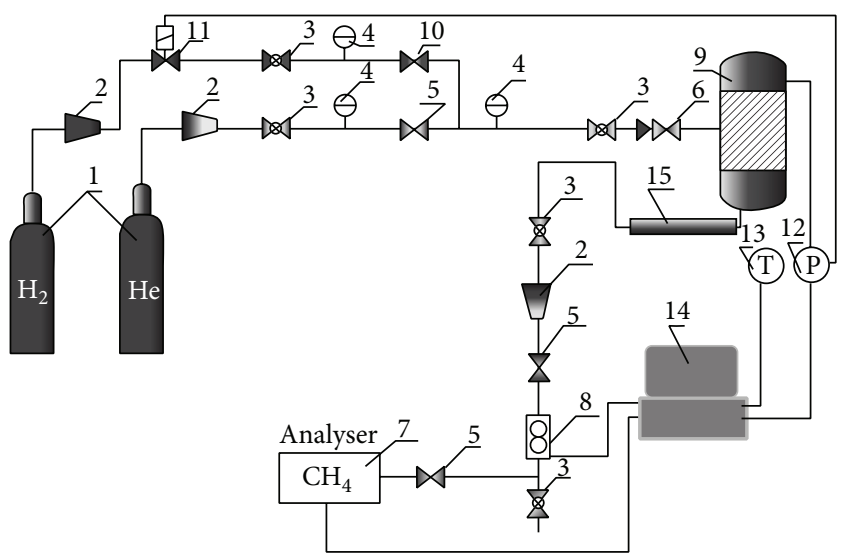

(a)

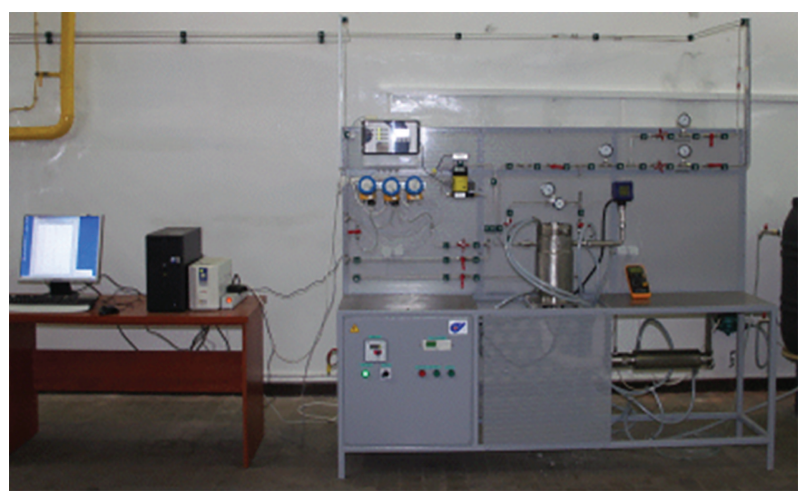

(b)

FIGURE 1: (a) Scheme: 1: gas cylinder, 2: pressure regulator, 3: cutoff value, 4: manometer, 5: control value, 6 : return valve, 7 : methane analyzer, 8: flow meter, 9: reactor, 10: single stage pressure regulator, 11: electromagnetic valve, 12: pressure converter, 13: thermocouple, 14: computer, 15: cooler and (b) view of the experimental facility.

of up to $30 \mathrm{~g}$ samples with the following parameters: a hydrogen flow rate of $0.1-10 \mathrm{dm}_{\mathrm{n}}{ }^{3} / \mathrm{min}$, pressure of up to $10 \mathrm{MPa}$, and temperature of up to $1273 \mathrm{~K}$. The reactor was equipped with electrical sample heating system $(1 \mathrm{~K} / \mathrm{s})$ ensuring simultaneous hydrogen heating to the process temperature. When the samples were placed inside the reactor, it was flushed with helium and then filled with hydrogen. The hydrogen flow rate was stabilised ( $\pm 1.5 \%$ deviation $)$ in a mass flow controller.

Measurements of $\mathrm{CH}_{4}$ concentration in the process gas were performed using a microprocessor analyser with infrared absorption detectors. An analyser with two MG$73 / \mathrm{CH}_{4}$ measuring heads $(0-5 \%$ and $0-100 \%)$ as well as an MSMR-4 microprocessor recording system was used.

The process parameters were recorded in accordance with a set mode of $5 \mathrm{~s}$ intervals. A view of the experimental facility is presented in Figure 1(b). A module design of the facility allowed for further expanding the measurement and flow channels of the process gases. It allowed, in particular, for delivering mixtures of hydrogen and an additional reagent to the process.

Calculations for two extreme cases, that is, $973 \mathrm{~K}$ and $6 \mathrm{MPa}$ as well as $1273 \mathrm{~K}$ and $10 \mathrm{MPa}$, were performed. For each case, distribution of thermal fields and flows in an empty reactor and in a reactor containing $10 \mathrm{~g}$ of coal was considered. While modelling the char-filled reactor, calculations for multiphase flows were necessary and the stationary bed with a solid phase containing mean $0.8 \mathrm{~mm}$ particles was approximated. The calculations resulted in flow parameter fields typical of reactors that operate under two extreme experimental conditions, which was ensured by the gas swirler design.

The char was produced during $30 \mathrm{~min}$ pyrolysis (heating rate of $100 \mathrm{~K} / \mathrm{s}$ ) in helium at $2 \mathrm{MPa}$ and $1373 \mathrm{~K}$. The char samples were sieved to the group of $0.6-1.0 \mathrm{~mm}$ particle size. The "Janina" subbituminous coal and the "Szczerców" lignite were used during the experiments, of the characteristics described in Table 1 .

The measured molar methane content was used to calculate the rate of hydrogasification reactions. Because hydrogen was supplied to the reactor, while the measured molar gas stream $\dot{n}_{g}$ leaving the reactor contained both hydrogen and methane, the rate of hydrogasification, $\stackrel{\circ}{R}$, equivalent to the rate of methane produced, was calculated using the equation:

$$
\stackrel{\circ}{R}=\stackrel{\circ}{n}_{g} \mathrm{CH}_{4} \text {. }
$$

The number of carbon moles remaining in the reactor in the solid char at time $t$ is as follows:

$$
n_{C}(t)=n_{C}(0)-\int_{0}^{t} \dot{n}_{g} \mathrm{CH}_{4} d t,
$$

where $n_{C}(0)$ is the initial number of carbon moles in the char sample.

The char hydrogasification experiments were performed on $10 \mathrm{~g}$ samples of the "Janina" and "Szczerców" coals. The hydrogasification schedule involved experiments at 973, 1073 , and $1173 \mathrm{~K} ; 6,7$, and $8 \mathrm{MPa}$; and hydrogen flow rate of $0.5,2$, and $5 \mathrm{dm}_{\mathrm{n}}^{3} / \mathrm{min}$ in the following series: $5 \mathrm{dm}_{\mathrm{n}}{ }^{3} / \mathrm{min}$; 973-1173 K; 6-8 MPa; $2 \mathrm{dm}_{\mathrm{n}}{ }^{3} / \mathrm{min}$; 973-1173 K; 6-8 MPa; $0.5 \mathrm{dm}_{\mathrm{n}}{ }^{3} / \mathrm{min} ; 973-1173 \mathrm{~K} ; 6-8 \mathrm{MPa}$. Duration of each experiment was different and determined at the reaction completion.

The "Janina" and "Szczerców" coal hydrogasification schedule involved experiments with $10 \mathrm{~g}$ samples at 973 and $1173 \mathrm{~K}, 8 \mathrm{MPa}$ and hydrogen flow rate of $0.5 \mathrm{dm}^{3} / \mathrm{min}$.

The schedule of hydrogasification in the $\mathrm{CO}_{2}$-diluted hydrogen for the "Janina" char was followed for a mixture of $\mathrm{H}_{2}+10 \% \mathrm{CO}_{2}$ and involved experiments at 973, 1073, and $1173 \mathrm{~K} ; 8 \mathrm{MPa}$; hydrogen flow rate of $0.5 \mathrm{dm}_{\mathrm{n}}{ }^{3} / \mathrm{min}$, with $10 \mathrm{~g}$ samples. Duration of each experiment was different and determined at the reaction completion. The investigations were performed for the maximum pressure value of $8 \mathrm{MPa}$ and the lowest gas flow rate of $0.5 \mathrm{dm}_{\mathrm{n}}{ }^{3} / \mathrm{min}$ as under these conditions, the maximum methane concentration was obtained in the hydrogasification experiments conducted in pure hydrogen.

\section{Results and Discussion}

3.1. Carbon Conversion and Methane Content. Effects of the hydrogasification isothermal stage temperature (1073, 
TABLE 1: Characteristics of coals used.

\begin{tabular}{lccccccc}
\hline Coal & $\mathrm{W}^{\mathrm{a}}, \%$ & $\mathrm{~V}^{\mathrm{a}}, \%$ & $\mathrm{~A}^{\mathrm{a}}, \%$ & $\mathrm{C}^{\mathrm{a}}, \%$ & $\mathrm{H}^{\mathrm{a}}, \%$ & $\mathrm{~S}^{\mathrm{a}}, \%$ & $\mathrm{~N}^{\mathrm{a}}, \%$ \\
\hline "Janina" coal & 10.21 & 32.41 & 9.46 & 62.73 & 3.94 & 1.45 & 0.84 \\
"Szczerców" lignite & 12.97 & 37.53 & 23.07 & 42.63 & 3.21 & 2.48 \\
\hline
\end{tabular}

${ }^{a}$ Analytical state.

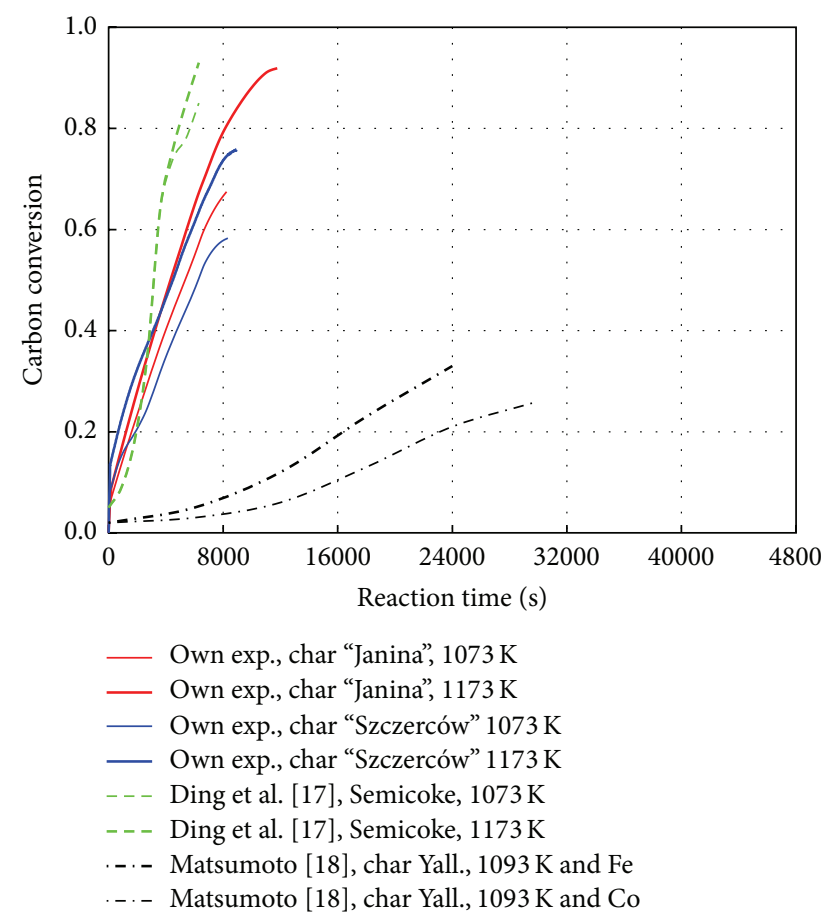

FIGURE 2: Influence of temperature on carbon conversion rate.

$1173 \mathrm{~K}$ ) on the char conversion rate at $6 \mathrm{MPa}$ for the "Janina" char are presented in Figure 2. The findings were compared to the results obtained by Ding et al. [17] for the "Inner Mongolia Semicoke" at the same temperatures and at the pressure of $5 \mathrm{MPa}$, as well as to the experiments performed by Matsumoto [18] for the "Yallourm" char at $1093 \mathrm{~K}$ and $0.1 \mathrm{MPa}$ with a catalyst: iron $(0.80 \% \mathrm{Fe})$ and cobalt $(0.92 \% \mathrm{Co})$. For the "Janina" char, the maximum conversion rate at $1073 \mathrm{~K}$ was comparable to that obtained by Ding et al., while at $1173 \mathrm{~K}$, it was lower by $18 \%$. With the additive of iron, the results of catalytic hydrogasification obtained by Matsumoto were approximately 2 -fold lower than the findings for the "Janina" char, while with the cobalt additive, they were approximately 2.5 -fold lower. The conversion rates were clearly affected by low pressure despite the use of catalysts. Similar results to Matsumoto's findings were obtained by Lee et al. [19] for the "Datong" coal, which was gasified with hydrogen at $973 \mathrm{~K}$ and $6 \mathrm{MPa}$.

Effects of the hydrogasification isothermal stage temperature $(973,1073$, and $1173 \mathrm{~K}$ ) and pressure (6, 7, and $8 \mathrm{MPa}$ ) are presented in Figures 3(a) to 3(c) for the "Janina" char and in Figures 4(a) to 4(c) for the "Szczerców" chars, respectively. For each plot, a hydrogasification onset was assumed to be the moment when the maximum methane concentration was achieved for the process temperature. A stepped shape of the lines in the figures is a result of the applied gas analyser resolutions: for $0-5 \%$ methane, the measurement accuracy was $0.1 \%$ while for concentrations above $5 \%$, the accuracy was $1 \%$. The highest $\mathrm{CH}_{4}$ molar fractions (approximately 8\% and 7\% for the "Janina" and "Szczerców" chars, resp.) were reported for $1173 \mathrm{~K}$ and $8 \mathrm{MPa}$, while the lowest values (approximately $2 \%$ and $1.6 \%$ for the "Janina" and "Szczerców" chars, resp.) were recorded at $973 \mathrm{~K}$ and $6 \mathrm{MPa}$. The temperature rise by $200 \mathrm{~K}$ and the pressure rise by $2 \mathrm{MPa}$ allowed for obtaining more than twofold higher $\mathrm{CH}_{4}$ fractions.

3.2. Char Reactivity. For industrial applications, important technological parameters are char reactivity in the hydrogasification process and its relationship with the solid carbon conversion rate. In the literature, experimental facts suggestive of strong char reactivity reduction during hydrogasification at high conversion rates $[1,2,20]$ can be found. Such reduction, which impedes achievement of a solid carbon high conversion rate, has resulted in a search of industrial technological solutions that will ensure maintaining major hydrogasification benefits. This is a basis for a process involving two reactors [21]: a reactor for coal hydropyrolysis and a reactor for char gasification.

The process is aimed at synthetic natural gas (SNG) and benzene/toluene/xylene mixture (BTX) production with the energy performance of approximately $77 \%$, which is far higher than the $63 \%$ value obtained for the SNG production technology based on methanation of synthesis gas obtained by coal gasification with steam and oxygen [22]. The process parameters, basically pressure and temperature, are selected based on the structures of expected final products. The hydropyrolysis reaction at a moderate pressure of approximately $3 \mathrm{MPa}$ and a temperature of up to $1143 \mathrm{~K}$ suggests a potential for achieving up to $88 \%$ energy performance with two final products: fuel gas $\left(\mathrm{H}_{2}, \mathrm{CO}\right.$, and $\left.\mathrm{CH}_{4}\right)$ and light oils [21]. For only SNG or BTX production, a higher process pressure of up to $8 \mathrm{MPa}$ is necessary, which results in process energy performance reduction to approximately $77 \%$.

Reactivity of chars, expressed as a ratio of produced methane molar stream to a current number of moles of carbon remaining in the solid state in the reactor, was determined based on the experiments performed for the "Janina" and "Szczerców" coal chars. In Figure 5, results for $6 \mathrm{MPa}$ at three temperatures, $973 \mathrm{~K}, 1073 \mathrm{~K}$, and $1173 \mathrm{~K}$, are presented. The figures show that initially, hydrogasification proceeded with almost stable reactivity (or even mildly increasing), while in the finale stage, a rapid reactivity drop was observed. For the highest temperature of $1173 \mathrm{~K}$, the rapid reactivity drop began at approximately $70 \%$ and from 


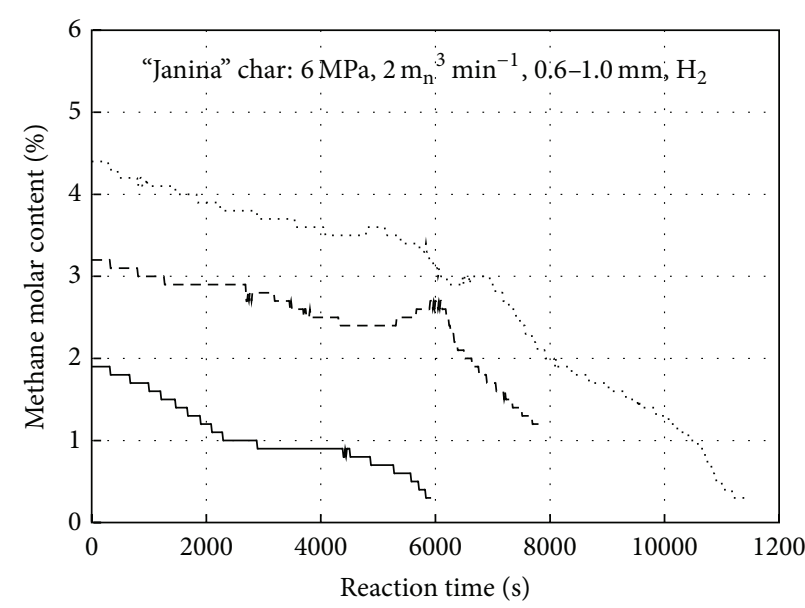

(a)

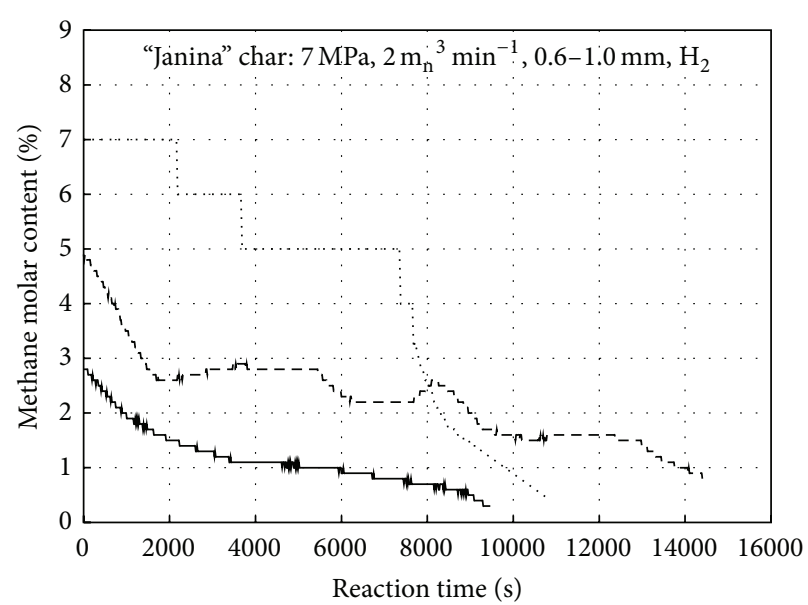

(b)

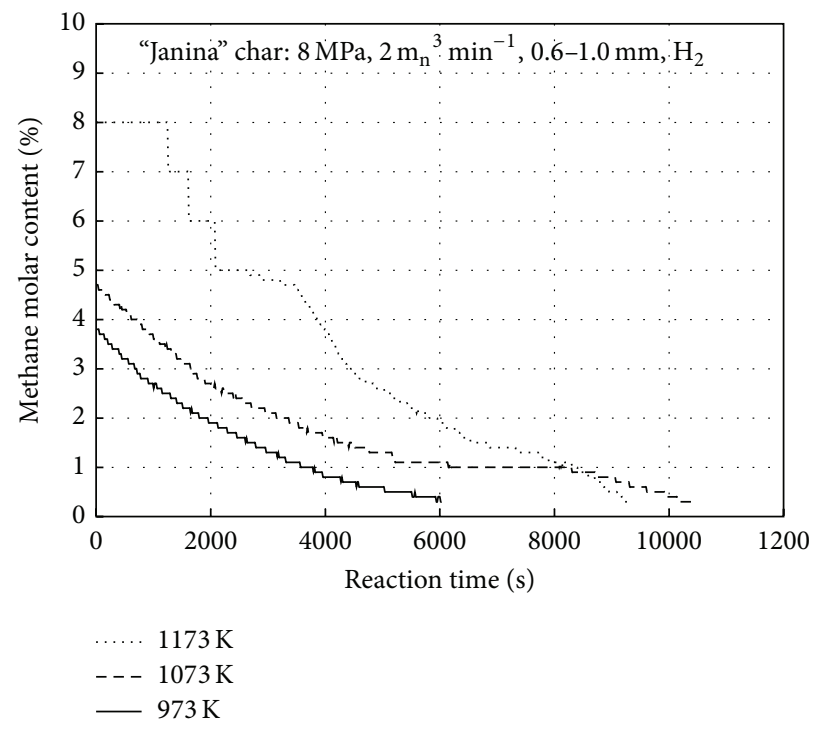

(c)

FIGURE 3: Measured molar content of the outflow gas methane versus time for "Janina" char at 1173, 1073, and $973 \mathrm{~K} \mathrm{for} \mathrm{(a)} 6 \mathrm{MPa}$, (b) $7 \mathrm{MPa}$, and (c) $8 \mathrm{MPa}$.

approximately $90 \%$ carbon conversion rate for the "Szczerców" and "Janina" chars, respectively. The investigations do not confirm previous observations of gradual char reactivity reduction. Mühlen [2] observed a continuous, relatively mild reactivity drop during hydrogasification at $4 \mathrm{MPa}$. At the coal conversion degree of approximately $90 \%$, the reactivity drop was about $75 \%$ of the initial value. On the other hand, Anthony et al. [9] observed a rapid reactivity drop as early as at the $10 \% \mathrm{C}$ conversion degree during char hydrogasification at $873 \mathrm{~K}, 998 \mathrm{~K}$, and $3.3 \mathrm{MPa}$. The results presented in Figure 5 show that for the lowest investigated temperature, $973 \mathrm{~K}$, a reactivity drop can be assumed to start as early as from the hydrogasification onset. However, for $1073 \mathrm{~K}$ and $1173 \mathrm{~K}$ in particular, a rapid reactivity drop did not occur until the carbon conversion rate was above $60 \%$ and $80 \%$, respectively. This means that, to obtain a high degree of carbon conversion, a temperature of approximately $1200 \mathrm{~K}$ is necessary during char hydrogasification.

3.3. Coal Hydrogasification. The "Janina" and "Szczerców" coal hydrogasification schedule involved experiments with $10 \mathrm{~g}$ samples at 973,1073 , and $1173 \mathrm{~K} ; 8 \mathrm{MPa}$; and hydrogen flow rate of $0.5 \mathrm{dm}^{3} / \mathrm{min}$. During the coal hydrogasification experiments, no transfer of liquid tarry substances with the process gas or adhesion to the gas outflow channels were observed, which means that the tarry products of the devolatilisation stage in the hydrogen atmosphere were mainly conversed to the $\mathrm{C}_{1}-\mathrm{C}_{3}$ gaseous form. Deep conversion of the tarry substances resulted from relatively long retention time of the gaseous phase (approximately $6 \mathrm{~s}$ ) in the high temperature zone. Dobner et al. [23] demonstrated that, under similar coal hydrogasification conditions, a $3 \mathrm{~s}$ stay of 


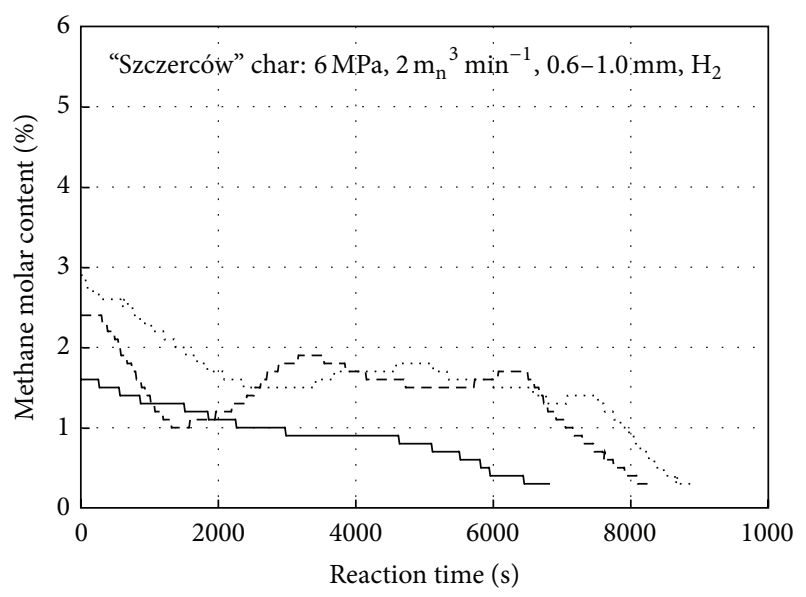

(a)

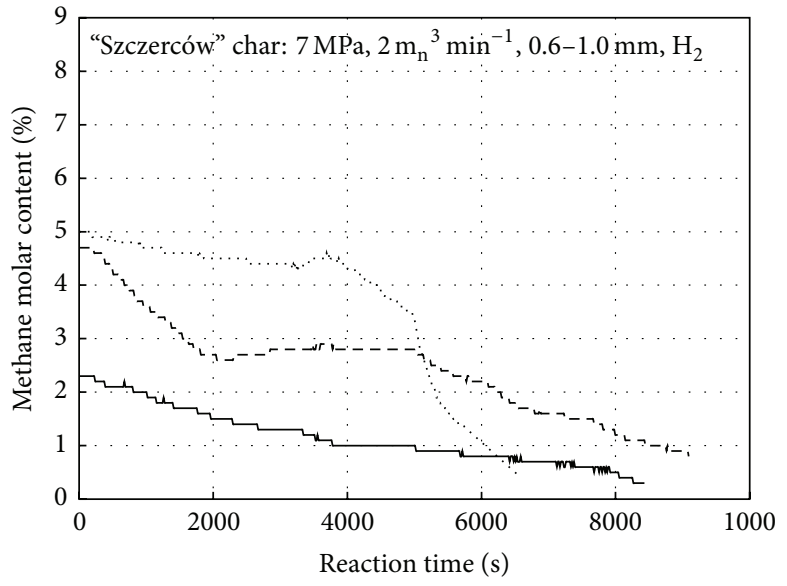

(b)

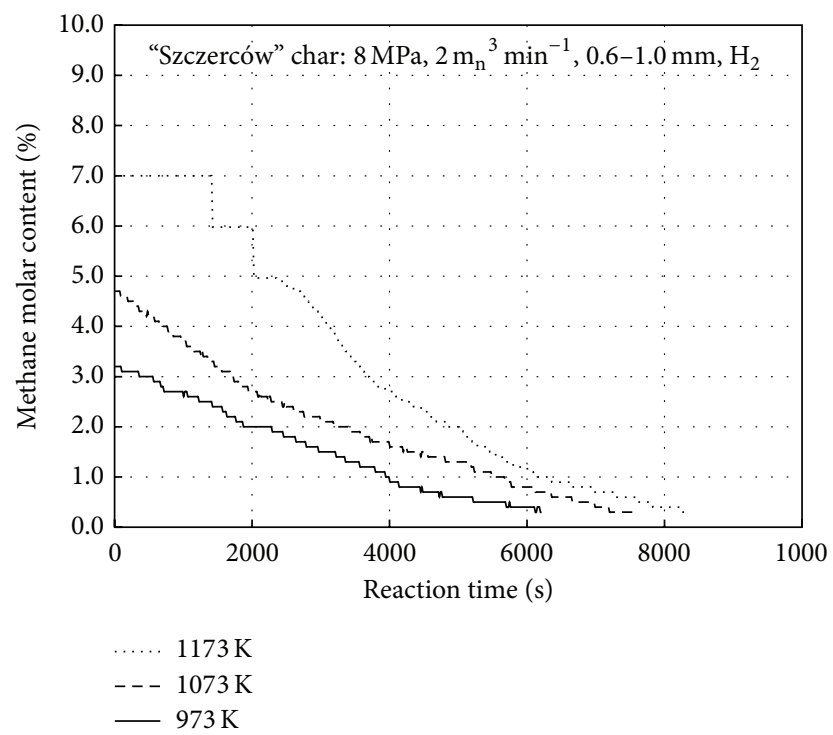

(c)

Figure 4: Measured molar content of the outflow gas methane versus time for "Szczerców" char at 1173, 1073, and 973 K for (a) 6 MPa, (b) $7 \mathrm{MPa}$, and (c) $8 \mathrm{MPa}$.

the gaseous phase in the reactor was sufficient for complete conversion of the tarry substances to gaseous hydrocarbons.

Results of maximum molar fraction measurements for methane contained in the process gas versus time for the "Janina" and "Szczerców" coals at the hydrogasification isothermal stage temperatures (1173 K and $973 \mathrm{~K}$ ) against hydrogasification of their chars are presented in Table 2. Maximum methane fractions in the process gas were observed in the initial hydrogasification stage and they were temperaturedependent. For the maximum temperature of $1173 \mathrm{~K}$, in the coal hydrogasification case, the methane fraction was approximately $40 \%$ lower than for the char. For $973 \mathrm{~K}$, coal hydrogasification resulted in a gas of higher methane content than in the case of char hydrogasification. This relationship was a result of hydropyrolysis and hydrogasification overlap. The hydrogasification process at $973 \mathrm{~K}$ was more than twofold slower, so its contribution to methane production at lower temperatures was less important compared to hydropyrolysis, while at high temperatures, the situation was reversed, due to intense methane production during char hydrogasification. A significant reaction may be development of the inner surface of char particles resulting from their preparation at $1273 \mathrm{~K}$, which was higher than the hydrogasification temperatures of $973 \mathrm{~K}$ or $1173 \mathrm{~K}$.

3.4. Char Hydrogasification in the $\mathrm{H}_{2}+\mathrm{CO}_{2}$ Atmosphere. A technological process of hydrogasification requires elimination of carbon dioxide following synthesis gas-contained $\mathrm{CO}$ conversion. The final hydrogen purity affects the process economy and has clear technological consequences for the hydrogasification stage. To check this, hydrogasification in a carbon dioxide-diluted hydrogen atmosphere was investigated for the $\mathrm{H}_{2}+10 \% \mathrm{CO}_{2}$ mixture. The experiments were performed at the highest pressure of $8 \mathrm{MPa}$ and for 


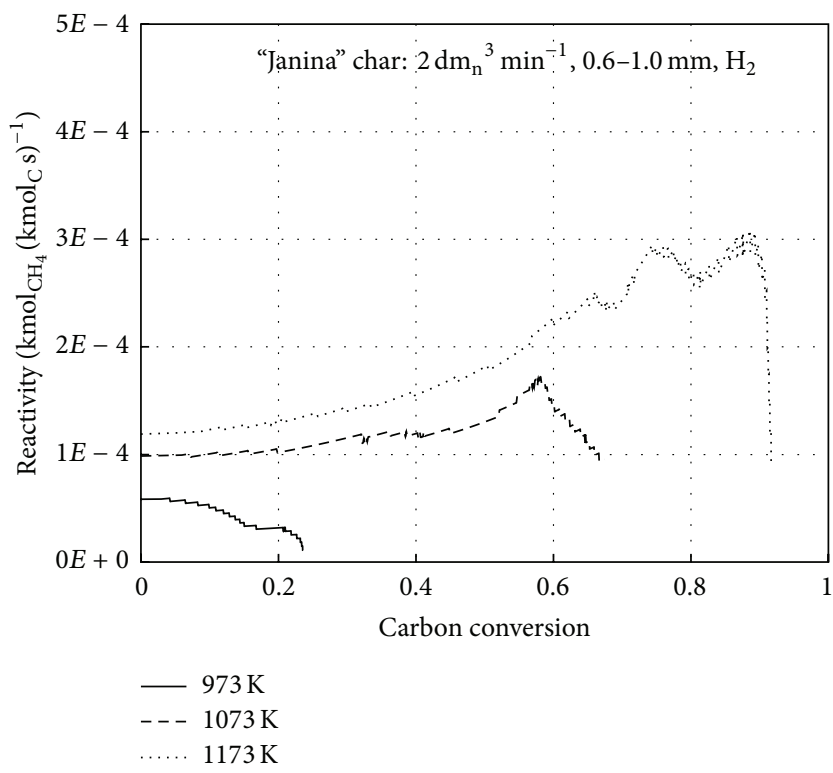

(a)

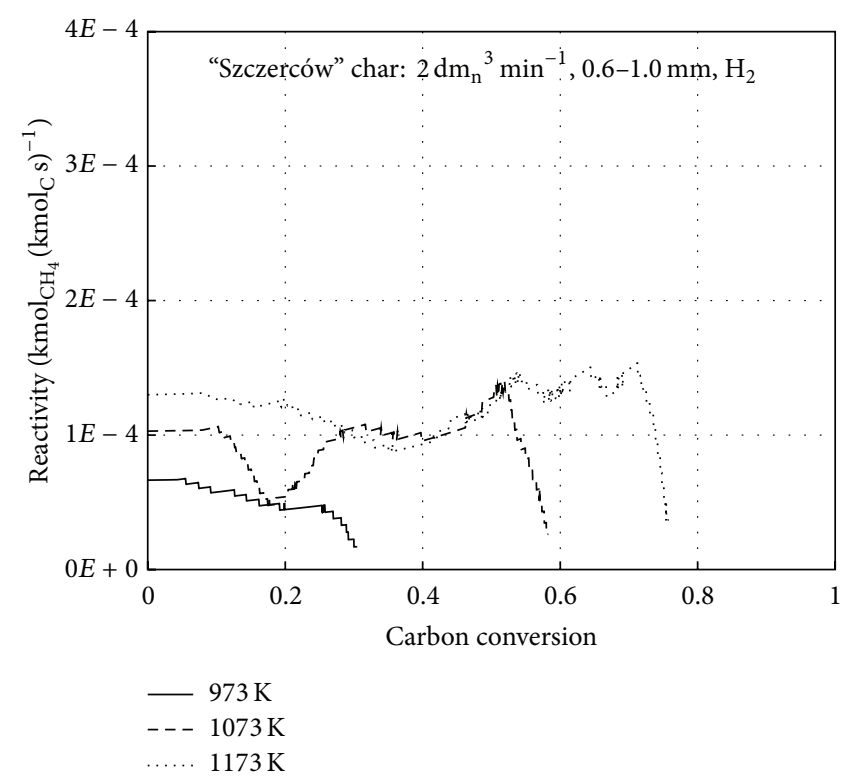

(b)

FIGURE 5: Hydrogasification reactivity versus carbon conversion time for (a) "Janina” and (b) "Szczerców” char.

TABLE 2: Maximum methane molar content in the outflow gas in hydrogasification at $8 \mathrm{MPa}$ and hydrogen flow rate of $0.5 \mathrm{dm}_{\mathrm{n}}^{3} / \mathrm{min}$.

\begin{tabular}{lccc}
\hline Sample & \multicolumn{3}{c}{ Methane molar content, \% } \\
& $973 \mathrm{~K}$ & $1073 \mathrm{~K}$ & $1173 \mathrm{~K}$ \\
\hline "Janina" & & & \\
Coal & 4.3 & 4.9 & 5.9 \\
Char & 3.8 & 4.7 & 10.0 \\
"Szczerców" & & & \\
Coal & 2.9 & 3.2 & 3.7 \\
Char & 1.6 & 3.4 & 6.1 \\
\hline
\end{tabular}

one gas flow rate of $0.5 \mathrm{dm}_{\mathrm{n}}{ }^{3} / \mathrm{min}$ at three temperatures: 973 , 1073 , and $1173 \mathrm{~K}$. As the maximum methane concentrations obtained during the experiments were higher than those obtained during gasification in hydrogen, a role of methane generation during a homogenous reaction in the $\mathrm{H}_{2}+10 \%$ $\mathrm{CO}_{2}$ mixture was investigated. For this purpose, a carrier gas was delivered to the reactor without a char sample under the same thermal conditions.

Results of measurements of methane molar fraction in the process gas for the "Janina" char are presented in Table 3. The highest (approximately 20\%) and the lowest (approximately 8-9\%) $\mathrm{CH}_{4}$ molar fractions were reported for $1173 \mathrm{~K}$ and $973 \mathrm{~K}$, respectively. Under the comparable conditions of char hydrogasification in pure hydrogen, the obtained maximum methane concentrations were markedly lower. A fraction of methane generated in homogenous reactions of $\mathrm{CO}_{2}$ and $\mathrm{H}_{2}$ was about $40-50 \%$ of the total content at the highest recorded concentrations for all three investigated cases (as apparent from the analysis of Table 3).
TABLE 3: Comparison of the maximum molar methane content in the outflow gas.

\begin{tabular}{lcc}
\hline Temperature & $\mathrm{H}_{2}$ & $\mathrm{H}_{2}+10 \% \mathrm{CO}_{2}$ \\
\hline $973 \mathrm{~K}$ & $3.8 \%$ & $9 \%$ \\
$1073 \mathrm{~K}$ & $4.7 \%$ & $13 \%$ \\
$1173 \mathrm{~K}$ & $10 \%$ & $20 \%$ \\
\hline
\end{tabular}

In the experiments of hydrogasification in the $\mathrm{H}_{2}+10 \%$ $\mathrm{CO}_{2}$ atmosphere, generation of significant $\mathrm{CH}_{4}$ amounts in the reactor without solid carbon was demonstrated. As shown in Table 3 , the methane fraction at the reactor outflow point may reach up to approximately $20 \%$ at $8 \mathrm{MPa}$ and $1173 \mathrm{~K}$. To assess technological consequences of $\mathrm{CO}_{2}$ effects on the hydrogasification process, an equilibrium analysis of the products leaving the reactor was performed for $1173 \mathrm{~K}$ and $8 \mathrm{MPa}$ process parameters. It was assumed that the solid reagent was char $(\mathrm{C})$, while the calculations were performed for the equal to one molar ratio of the inlet gas amounts to the $\mathrm{C}$. The molar fraction of $\mathrm{CO}_{2}$ in the inlet gas was analysed within the 0 to 1 range and compositions of hydrogasification products at the chemical equilibrium were determined for a six-component system: $\mathrm{H}_{2}, \mathrm{CO}_{2}, \mathrm{CO}, \mathrm{H}_{2} \mathrm{O}, \mathrm{CH}_{4}$, and C. In Figure 6, the equilibrium fraction of methane in the char hydrogasification gas with respect to the initial $\mathrm{CO}_{2}$ content in the carrier gas $\left(\mathrm{H}_{2}+\mathrm{CO}_{2}\right)$ is presented. The plot analysis shows that the $\mathrm{CO}_{2}$ fraction in the carrier gas markedly affects the equilibrium methane content in the produced process gas: for only $20 \% \mathrm{CO}_{2}$ in the carrier gas, the $\mathrm{CH}_{4}$ fraction was reduced by a half. Moreover, a line representing methane content in the gas leaving the reactor without a char sample is presented. In this case, 


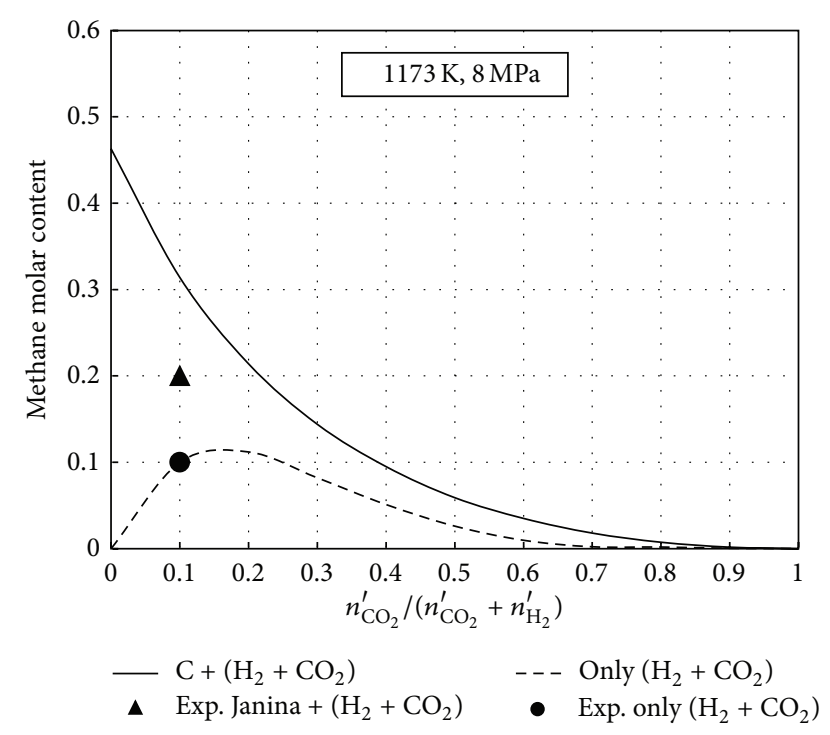

FIGURE 6: $\mathrm{CH}_{4}$ molar fraction in the hydrogasification products with respect to $\mathrm{CO}_{2}$ content in the inlet gas.

methane is produced during homogenous reactions in a fivecomponent system: $\mathrm{H}_{2}, \mathrm{CO}_{2}, \mathrm{CO}, \mathrm{H}_{2} \mathrm{O}$, and $\mathrm{CH}_{4}$. While comparing the experimental results for $1173 \mathrm{~K}$ in Table 3 to the lower line in Figure 6, it is clearly seen that the gas leaving the reactor without a char sample reached the equilibriumclose state, while the char hydrogasification reaction was approximately $10 \%$ higher for the $\mathrm{CH}_{4}$ molar fraction. It means that $10 \% \mathrm{CO}_{2}$ in the hydrogen-rich inlet gas enhanced the hydrogasification process, which should have beneficial technological consequences.

\section{Conclusions}

Consider the following:

(1) Essential parameters for coal hydrogasification in pure hydrogen with respect to the process performance are pressure, temperature, and a flow rate of hydrogen delivered to the reaction.

(2) A high degree of char hydrogasification can be achieved by performing the process at approximately $1200 \mathrm{~K}$.

(3) The hydrogasification process at $973 \mathrm{~K}$ is more than twofold slower than at $1173 \mathrm{~K}$, so hydrogasification contribution to methane production at lower temperatures is less important compared to hydropyrolysis while at high temperatures, the situation is reversed due to intense methane production during char hydrogasification.

(4) Reactivity of the "Szczerców" lignite char is comparable to reactivity of the "Janina" coal within the investigated technical parameter range.

(5) Under similar conditions of char hydrogasification in the hydrogen atmosphere with the $10 \%$ carbon dioxide additive, markedly higher maximum methane concentrations were obtained than those obtained during hydrogasification in pure hydrogen.

(6) The additive of approximately $10 \%$ carbon dioxide to hydrogen markedly enhances the process of char hydrogasification.

\section{Conflict of Interests}

The authors declare that there is no conflict of interests regarding the publication of this paper.

\section{References}

[1] J. L. Johnson, Kinetics of Coal Gasification, John Wiley \& Sons, New York, NY, USA, 1979.

[2] H. J. Mühlen, Zum Einflu $\beta$ der Produktgase auf die Kinetik der Wasserdamfvergasung in Abhängigkeit von Druck und Temperatur [Doktor Arbeit], 1983.

[3] J. Blackwood, "The reaction of carbon with hydrogen at high pressure," Australian Journal of Chemistry, vol. 12, no. 1, pp. 1428, 1959.

[4] J. Blackwood and D. McCarthy, "The mechanism of hydrogenation of coal to methane," Australian Journal of Chemistry, vol. 19, no. 5, pp. 797-813, 1966.

[5] A. Karcz and S. Porada, "Formation of C1-C3 hydrocarbons during pressure pyrolysis and hydrogasification in relation to structural changer in coal," Fuel, vol. 74, no. 6, pp. 806-809, 1995.

[6] A. Karcz and S. Porada, "The influence of coal rank on formation of gaseous hydrocarbons in hydrogasif ication of coal," Fuel, vol. 75, no. 5, pp. 641-645, 1996.

[7] F. Moseley and D. Paterson, "The rapid high-temperature hydrogenation of coal chars. Part 1: hydrogen pressures up to 100 atmospheres," Journal of the Institute of Fuel, vol. 13, pp. 1323, 1965.

[8] R. L. Zahradnik and R. A. Glenn, "Direct methanation of coal," Fuel, vol. 50, no. 1, pp. 77-90, 1971.

[9] D. B. Anthony, J. B. Howard, H. C. Hottel, and H. P. Meissner, "Rapid devolatilization and hydrogasification of bituminous coal," Fuel, vol. 55, no. 2, pp. 121-128, 1976.

[10] E. M. Suuberg, W. A. Peters, and J. B. Howard, "Product compositions in rapid hydropyrolysis of coal," Fuel, vol. 59, no. 6, pp. 405-412, 1980.

[11] D. Bunthoff, Bildungskinetik der BTX-Aromaten bei der Druckpyrolyse von Steinkohlen in Stickstoff und Wesserstoff atmosphere [Doktor Arbeit], University of Duisburg-Essen, Essen, Germany, 1982.

[12] K. Krabiell, Zum Ablauf der Sekundärreactionen während der Druckpyrolyse von Steinkohlen bei niedrigen Aufheizgeschwindigkeiten [Doktor Arbeit], University of Duisburg-Essen, Essen, Germany, 1996.

[13] M. Kaiser, Primär und Sekundärreactionen bei der Pyrolyse und Hydropyrolyse von Steinkohlen unter hohen Aufheizgeschwindigkeiten [Doktor Arbeit], University of Duisburg-Essen, Essen, Germany, 1986.

[14] U. Treuling, Kohlenwerkstoff gewinnung aus Teeren der Druckpyrolyse von Steinkohlen unter inerten und reaktiven Gasen [Doktor Arbeit], Aachen, Germany, 1985.

[15] A. C. Sheth, C. Sastry, Y. D. Yeboah, Y. Xu, and P. Agarwal, "Catalytic gasification of coal using eutectic salts: reaction 
kinetics for hydrogasification using binary and ternary eutectic catalysts," Fuel, vol. 83, no. 4-5, pp. 557-572, 2004.

[16] J. Tomeczek and S. Gil, "The kinetics of coal chars hydrogasification," Fuel Processing Technology, vol. 91, no. 11, pp. 1564-1568, 2010.

[17] X. Ding, Y. Zhang, T. Zhang, J. Tang, Y. Xu, and J. Zhang, "Effect of operational variables on the hydrogasification of inner Mongolian lignite semicoke," Energy and Fuels, vol. 27, no. 8, pp. 4589-4597, 2013.

[18] S. Matsumoto, "Catalyzed hydrogasification of yallourn char in the presence of supported hydrogenation nickel catalyst," Energy \& Fuels, vol. 5, no. 1, pp. 60-63, 1991.

[19] S. H. Lee, J. G. Lee, J. H. Kim, and Y. C. Choi, "Hydrogasification characteristics of bituminous coals in an entrained-flow hydrogasifier," Fuel, vol. 85, no. 5-6, pp. 803-806, 2006.

[20] M. E. Toomajian, M. G. Lussier, and D. J. Miller, "Effect of oxidation and other treatments on hydrogasification rate of coal char," Fuel, vol. 71, no. 9, pp. 1055-1061, 1992.

[21] "NEDO information, substitute natural gas from coalJapanese market demand," The Australian Coal Review, vol. 4, p. 38, 1997.

[22] H. Yabe, H. Kozuru, Y. Namiki et al., "Development of coal partial hydropyrolysis process," Nippon Steeel Technical Report 92, 2005, http://www.nssmc.com/en/tech/report/nsc/pdf/n9203 .pdf.

[23] S. Dobner, R. A. Graff, and A. M. Squires, "Flash hydrogenation of coal 2. Yield structure for Illinois No. 6 coal at 100 atm," Fuel, vol. 55, no. 2, pp. 113-115, 1976. 


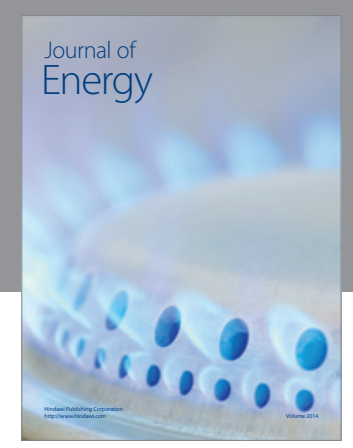

Journal of

Industrial Engineering
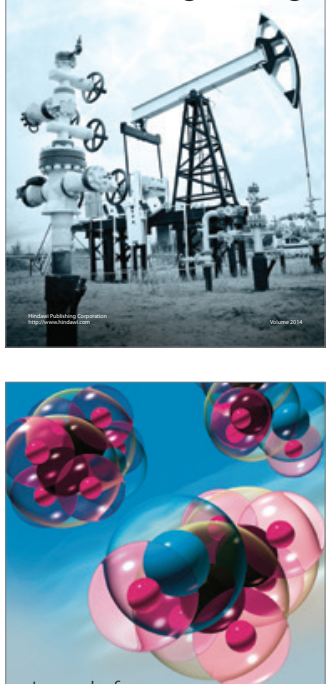

Fuels
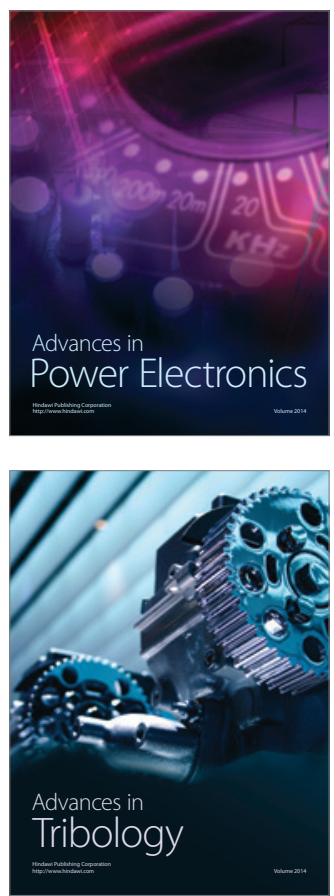

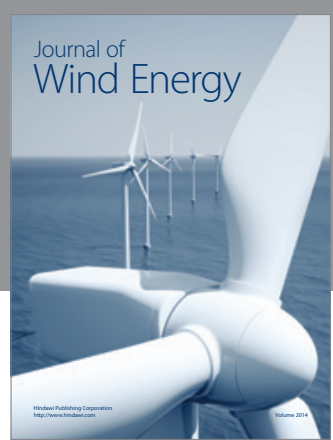

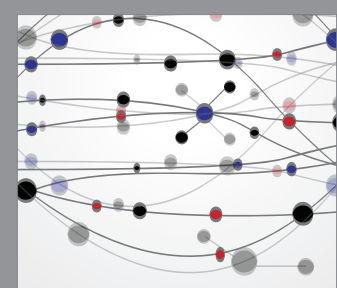

The Scientific World Journal

Submit your manuscripts at http://www.hindawi.com

Journal of

Structures
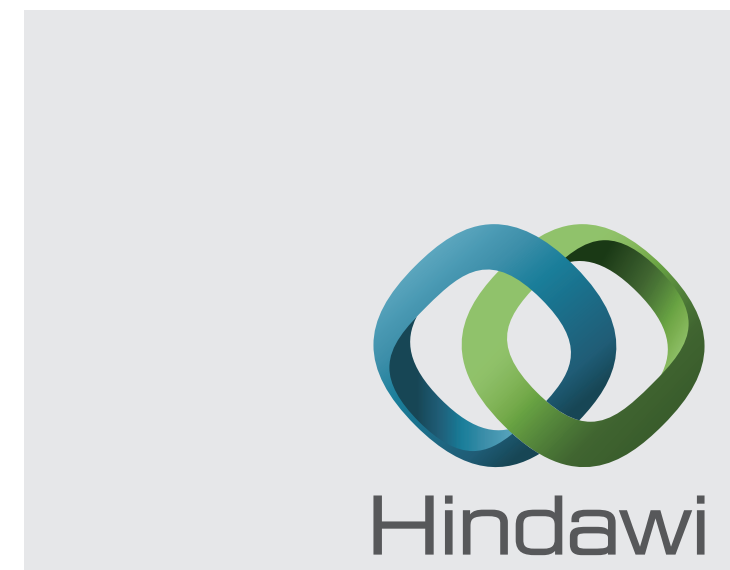

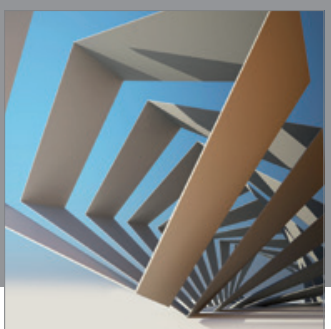

Rotating

Machinery
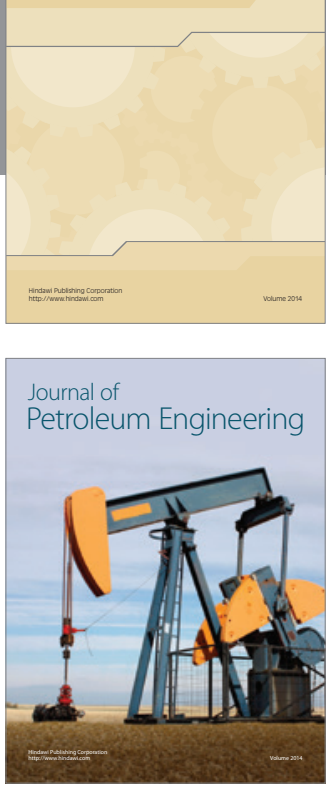

Journal of

Solar Energy
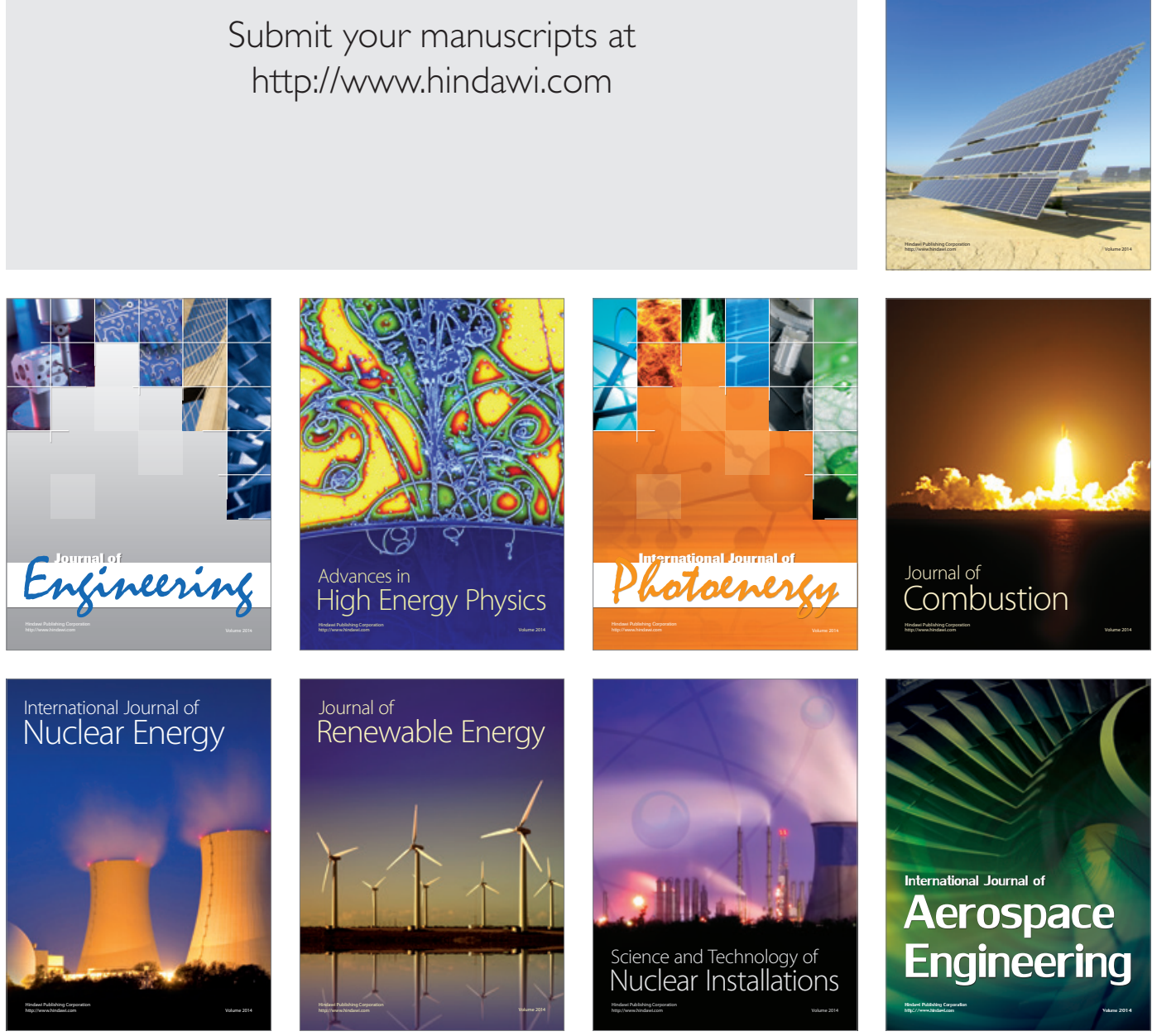